\title{
Wild and attenuated vaccine RS-12 strains of mumps virus exhibit differences in amino acid sequences of their proteins
}

\author{
B. ALIREZAIE ${ }^{1}$, R. SHAHBAZI ${ }^{1}$, S. S. SAFAVIEH ${ }^{2}$, A. MOHAMMADI ${ }^{1}$
}

\begin{abstract}
${ }^{1}$ Department of Human Viral Vaccines, Razi Vaccine and Serum Research Institute (RVSRI), Beheshti Blv, P.O. Box 31975/148, Karaj, Alborz, Iran; ${ }^{2}$ Department of Biotechnology, Razi Vaccine and Serum Research Institute (RVSRI), Beheshti Blv, P.O. Box 31975/148, Karaj, Alborz, Iran
\end{abstract}

Received November 11, 2013; accepted August 1, 2014

\begin{abstract}
Summary. - Attenuated mumps virus (MuV) RS-12 strain-based vaccine is one of several effective vaccines available in the prevention of mumps. Since previous studies have unveiled only about one-third of the attenuated vaccine RS-12 strain genome sequence, the rest of sequence and molecular basis for attenuation remained unsolved. Therefore, in this study, the full-length genome sequences of wild and attenuated RS-12 strains were determined and compared. The comparison revealed nucleotide substitutions at 9 positions leading to amino acid substitutions at 6 positions in $\mathrm{P}, \mathrm{V}, \mathrm{I}, \mathrm{M}$, and L proteins, while the remaining substitutions were silent. This result indicates that the observed mutations in $\mathrm{P}, \mathrm{V}, \mathrm{I}, \mathrm{M}$, and $\mathrm{L}$ proteins of $\mathrm{MuV}$ might be responsible for the attenuation of the RS-12 vaccine strain.
\end{abstract}

Keywords: mumps virus; vaccine; attenuation; mutation

\section{Introduction}

Mumps is a contagious disease caused by the mumps virus, a member of the Rubulavirus genus. The main sign of the disease is a non-suppurative painful swelling of one or both parotid glands, which largely recovers without any sequelae. Despite the fact that parotitis and inapparent infections are more common than sever form, in some cases other complications including orchitis, oophoritis, pancreatitis, meningitis, encephalitis, myocarditis, pericarditis, nephritis, and arthritis might develop. Mumps is classified as a vaccine-preventable disease. Mumps was in the past one of the most widespread diseases in the world; however, extensive use of less virulent viruses as a prophylactic device has dramatically reduced the rate of this disease in most parts of the world (Betáková et al., 2013). Attempts

E-mail: b.alirezaie@rvsri.ac.ir; phone: +98-263-4570038.

Abbreviations: $\mathrm{F}=$ fusion; $\mathrm{HN}=$ hemagglutinin-neuraminidase; $\mathrm{L}=$ large polymerase; $\mathrm{M}=$ matrix $\mathrm{MuV}=$ mumps virus; $\mathrm{N}=$ nucleoprotein; $\mathrm{P}=$ phosphoprotein; $\mathrm{SH}=$ small hydrophobic to develop live avirulent vaccines have previously met with success; for example, attenuated vaccine strain RS-12 is one of several effective mumps vaccinal strains derived from wild-type isolate. This strain was isolated in 1986 in Iran and was serially propagated in MRC- 5 cells (Sassani et al., 1991). As a consequence of consecutive passages, the wild RS-12 strain gradually evolved to display the properties of an attenuated strain. A previous study based on marker test and experimental infection of monkeys disclosed that attenuated RS-12 vaccine strain displayed phenotypically, clinically and histopathologically distinc features from its parental isolate (Sassani et al., 1991). Previous clinical trials also have showed that this vaccinal strain is efficacious and safe (Sassani et al., 1991; Esna-ashari et al., 2002; FeiternaSperling et al., 2005). A standard seed lot system for this strain has recently been established and subsidiary clinical trials are ongoing (Shahkarami et al., 2012). Although this isolate has been partially characterized, a molecular basis for attenuation remains to be determined. Phylogenetic analysis based on the entire SH gene determined that the wild RS-12 strain pertained to the genotype $\mathrm{H}$ and was located within the 
European strains that compose an entirely separate cluster from the Far Eastern isolates (Alirezaie et al., 2008).

In this study, we attempted to determine the sequence of the complete genome of $\mathrm{MuV}$, but mainly to compare the sequences of wild and attenuated vaccine RS-12 strains, and to reveal the nucleotide and amino acid changes, which had occurred during serial passaging and resulted in attenuation.

\section{Materials and Methods}

Virus. The supernatants of the wild RS-12 strain (second passage) and attenuated vaccine RS- 12 strain ( $19^{\text {th }}$ passage), which had been stored below $-70^{\circ} \mathrm{C}$, were thawed and used for sequence analysis.

RNA extraction. Viral RNAs were extracted from supernatant of infected tissue culture fluids using a High Pure Viral Nucleic Acid kit (Roche Applied Science, Mannheim, Germany) according to the manufacturer's instructions.

$R T$-PCR. Based on the alignment of all available MuV full-length genomes from the GenBank database, genus-specific primers for relatively conserved regions were designed using $\mathrm{Oligo}^{\circledR}$ software (version 5.0 [National Biosciences]). The primers used for PCR amplifications and/or sequencing are listed in $\mathrm{t} 1$.

Extracted RNAs were reverse-transcribed into cDNA using Expand Reverse Transcriptase (Roche Applied Science, Mannheim, Germany) at $42^{\circ} \mathrm{C}$ for $45 \mathrm{~min}$. The reaction mixture contained $1 \mathrm{X}$ buffer, $10 \mathrm{mmol} / \mathrm{l} \mathrm{DTT}, 1 \mathrm{mmol} / \mathrm{l}$ dNTPs, 20 U RNase inhibitor, 50 $\mathrm{U}$ expand reverse transcriptase, $50 \mu \mathrm{mol} / \mathrm{l}$ random hexamers, and 1 $\mu \mathrm{g}$ RNA. In order to achieve full-length genome sequencing, PCR fragments with overlaps were generated. The name and sequences of designed primers are shown in Table 1. All PCRs were run under the same conditions using Taq DNA polymerase in $50 \mu \mathrm{l}$ of reaction mixture comprising $1 \mathrm{X}$ PCR buffer $(10 \mathrm{mmol} / \mathrm{l}$ tris- $\mathrm{HCl}, 50 \mathrm{mmol} / \mathrm{l}$ $\mathrm{KCl}), 5 \mu \mathrm{cDNA}, 1.5 \mathrm{mmol} / \mathrm{l} \mathrm{MgCl}{ }_{2}, 0.5 \mu \mathrm{mol} / \mathrm{l}$ each primer, and 1 U SmantTaq DNA polymerase (CinnaGen, Tehran, Iran). Cycling was carried out using a Mastercycler thermocycler (Eppendorf) with the following cycle program: Initial denaturation at $95^{\circ} \mathrm{C}$ for $5 \mathrm{~min}$, followed by 30 cycles of $95^{\circ} \mathrm{C}$ for $1 \mathrm{~min}, 46^{\circ} \mathrm{C}$ for $1 \mathrm{~min}$ and $72^{\circ} \mathrm{C}$ for $2 \mathrm{~min}$, followed by a final extension of $15 \mathrm{~min}$ at $72^{\circ} \mathrm{C}$. With the purpose of decreasing the impact of possible nucleotide substitutions introduced by Taq DNA polymerase, high concentrations of template and primers were used. Moreover, each amplicon was amplified in five different tubes and subsequently pooled.

All nucleotide variations leading to amino acid substitutions were confirmed by the direct sequencing of the amplicons that were amplified using Pwo DNA polymerase (Roche Applied Science, Mannheim, Germany). To this end, the conditions for each primer pair (annealing temperatures, $\mathrm{MgSO}_{4}$ concentrations, and extension times) were optimized separately (Table 1$)$. Other parameters including cDNA template $(5 \mu \mathrm{l})$, dNTPs $(200 \mu \mathrm{mol} / \mathrm{l})$, primers ( $0.5 \mu \mathrm{mol} / \mathrm{l})$, buffer $(1 \mathrm{X})$, and Pwo DNA polymerase (2.5 U), were the same for all primer pairs.
Sequencing and sequence analysis. Sequencing was carried out directly on the pooled purified PCR product by Eurifins MWG, Ebersberg, Germany. The DNAMAN software package (version 4.13) was used for multiple DNA sequence alignment (MSA), gene assembly, protein translation, and protein alignment.

\section{Results and Discussion}

Although the accurate Pwo DNA polymerase enzyme possesses proofreading activity and its fidelity is about 10fold higher than Taq DNA polymerase, Pwo has relatively low specificity, especially when single stranded DNA is used as a template (Steffen et al., 1999; McPherson and Møller, 2006). Therefore, three precautionary measures were carried out in order to ensure the authenticity of the PCR products: (i) the optimal reaction conditions for each primer pair were determined individually to reduce non-specific amplification and PCR artifacts; (ii) the same products amplified with Taq DNA polymerase were included in each run as a positive control; (iii) high concentrations of first strand cDNAs were used.

The complete genome sequences of wild and attenuated vaccine strains RS-12 have been deposited in GenBank under Acc. Nos JQ388690 and JQ388691, respectively.

Multiple sequence alignment (MSA) revealed nucleotide substitutions at 9 positions leading to amino acid substitutions at 6 positions in $\mathrm{P}, \mathrm{V}, \mathrm{I}, \mathrm{M}$, and $\mathrm{L}$ proteins, while the remaining substitutions were silent (Table 2).

Recognition of nucleotide differences between the genome of the attenuated vaccine strain RS-12 and its parental wild isolate would be an indispensable step toward determining the basis of strain attenuation through consecutive passages in MRC- 5 cells. Multiple sequence alignments showed that the two genomes were identical in length. Moreover, noncoding regions, including the leader, trailer, transcription start and stop codons, intergenic regions as well as ORFs for the N, $\mathrm{F}$ and $\mathrm{SH}$ proteins, were identical between the two genomes, yet the genomes differed by 9 nucleotides in ORFs for the $\mathrm{P}$, $\mathrm{V}, \mathrm{I}, \mathrm{M}$, and L proteins. Amino acid variation detected in the $\mathrm{P}$ gene included a change at the position 2417 of the genome. The $\mathrm{N}$-terminal portion of the $\mathrm{P}$ gene ORF also encodes the $\mathrm{N}$-terminal regions of the $\mathrm{V}$ and I proteins. As a consequence, the $\mathrm{V}$ and I proteins contain the same amino acid substitution. Variation in the sequence of this region close to the insertion site has been reported previously in association with the accuracy of the insertion of non-templated $G$ in the gene transcripts and subsequently the accuracy of expression of these proteins in different mumps strains (Elliott et al, 1990). Analysis of the M protein revealed one predicted amino acid variation. Substitution in matrix proteins could contribute to the attenuation by affecting the efficiency of virus maturation. MSA also showed two predicted amino 
Table 1. Primers and reaction conditions used for amplification and sequencing of individual genes of MuV RS-12 strains

\begin{tabular}{|c|c|c|c|c|c|c|}
\hline \multirow[b]{2}{*}{$\begin{array}{l}\text { Gene / } \\
\text { protein }\end{array}$} & \multirow[b]{2}{*}{$\begin{array}{l}\text { Amplicon size } \\
\text { (bp) }\end{array}$} & \multirow[b]{2}{*}{$\begin{array}{l}\text { Primer } \\
\text { name }^{\mathrm{a}}\end{array}$} & \multirow[b]{2}{*}{ Sequence $\left(5^{\prime}-3^{\prime}\right)$} & \multicolumn{3}{|c|}{ PCR conditions using $P$ wo DNA polymerase } \\
\hline & & & & $\begin{array}{c}\mathrm{MgSO}_{4} \text { concentration } \\
(\mathrm{mmol} / \mathrm{l})\end{array}$ & $\begin{array}{c}\text { Annealing tempera- } \\
\text { ture }\left({ }^{\circ} \mathrm{C}\right)\end{array}$ & $\begin{array}{c}\text { Extension time } \\
(\mathrm{S})\end{array}$ \\
\hline \multirow{4}{*}{$\mathrm{N}$} & \multirow{2}{*}{1160} & $\mathrm{MuN}-1+$ & ACCAAGGGGAAAATGGAGAT & \multirow{2}{*}{2.5} & \multirow{2}{*}{46} & \multirow{2}{*}{60} \\
\hline & & MuN-1160- & CTCCCATAGCATAACTGAA & & & \\
\hline & \multirow{2}{*}{1217} & MuN-812+ & ATCAGGAAAAGTCTTGTTG & \multirow{2}{*}{2.5} & \multirow{2}{*}{46} & \multirow{2}{*}{60} \\
\hline & & MuN-2028- & CCTGTCTCAATTAAATCACC & & & \\
\hline \multirow{2}{*}{$\mathrm{P}$} & \multirow{2}{*}{1823} & MuP-1452+ & TGGAGGAATCAGATGACG & \multirow{2}{*}{1} & \multirow{2}{*}{47} & \multirow{2}{*}{90} \\
\hline & & MuP-3274- & GAGGAATTTTGATCTGTG & & & \\
\hline \multirow{4}{*}{ M } & \multirow{2}{*}{1403} & MuM-2720+ & GGTGACCCAAATAAAGAATG & \multirow{2}{*}{2.5} & \multirow{2}{*}{46} & \multirow{2}{*}{60} \\
\hline & & MuM-4122- & TGTGACCGCCTGCATGGA & & & \\
\hline & \multirow{2}{*}{1529} & MuM-3684+ & CAAATATCTGCGGACCAT & \multirow{2}{*}{2.5} & \multirow{2}{*}{46} & \multirow{2}{*}{60} \\
\hline & & MuM-5212- & CTTGTATACTAATCGGTGAC & & & \\
\hline \multirow{4}{*}{$\mathrm{F}$} & & MuF-4363+ & GGAAGTCTGCCTCAATGA & 2. & & \\
\hline & 985 & MuF-5347- & GCATCTCATCTAGCAGAAC & & 46 & 45 \\
\hline & & MuF-5149+ & GAATTAACAACAGTGTTTCAG & & & \\
\hline & 1105 & MuF-6253- & GTCACGAGACGTTACGAC & 2.5 & 46 & 60 \\
\hline $\mathrm{SH}$ & 1164 & MuSH-5656+ & GCACTGGATGGAACAATT & 25 & 46 & 60 \\
\hline SH & 1104 & MuSH-6819- & GACAACTGATTGCTCAAG & 2.3 & 40 & 00 \\
\hline & 1213 & MuHN-6236+ & GTCGTAACGTCTCGTGAC & & & \\
\hline $\mathrm{HN}$ & 1213 & MuHN-7449- & GTAAGTTTCTGGGTAGGTG & 2.5 & 46 & 60 \\
\hline HN & 1488 & MuHN-7202+ & GTAATTAATGCCAACTGC & & & \\
\hline & 1488 & MuHN-8689- & GATCCTTGCAATGAGTTC & 2.5 & 46 & 60 \\
\hline & 1266 & MuL-8323+ & CCAAATTCTACCTGTGCT & 25 & 46 & 60 \\
\hline & 1200 & MuL-9588- & TCTCGGACCTTGGATGCT & 2.5 & 40 & 00 \\
\hline & & MuL-9341+ & CAATTACAGTATGGTGATCC & & 46 & 45 \\
\hline & 953 & MuL-10293- & CTGTGCTCTGATATAATACC & 2.5 & 46 & 45 \\
\hline & 1289 & MuL-10064+ & GACCCTGAATTTTGTGCAT & 25 & 46 & \\
\hline & 1289 & MuL-11352- & CGTTTCACATCAGCAATTG & 2.5 & 46 & 60 \\
\hline $\mathrm{L}$ & & MuL-10995+ & TAAAGAACGTGAGCAAGATG & & & \\
\hline & 1256 & MuL-12250- & TAACACGAGTGGAAGCTAAC & 2 & 47 & 60 \\
\hline & 1550 & MuL-12164+ & GTATCACTTAAATCAGCACTC & 2.5 & 52 & 60 \\
\hline & 1550 & MuL-13713- & CTTGGGAGAGAGTATTTC & 2.5 & 52 & 60 \\
\hline & 2185 & MuL-13200+ & CCAACATTTCGCAAGGTA & 2.5 & 46 & 90 \\
\hline & 2100 & MuL-15384- & ACCAAGGGGAGAAAGTAAA & 2.0 & 40 & 80 \\
\hline
\end{tabular}

aThe numbers correspond to the nucleotide position of the $5^{\prime}$ ends of the synthetic primers relative to the genome.

Table 2. Nucleotide and amino acid substitutions in wild RS-12 strain due to its attenuation into vaccine strain

\begin{tabular}{|c|c|c|c|}
\hline Gene/protein & Nucleotide substitution & Codon change & Amino acid substitution \\
\hline $\mathrm{P}$ & $\mathrm{A} 2417 \mathrm{G}$ & $\mathrm{ACG} \rightarrow \mathrm{A} / \mathrm{GCG}$ & T147A or none \\
\hline V & A2417G & $\mathrm{ACG} \rightarrow \mathrm{A} / \mathrm{GCG}$ & T147A or none \\
\hline I & A2417G & $\mathrm{ACG} \rightarrow \mathrm{A} / \mathrm{GCG}$ & T147A or none \\
\hline \multirow[t]{3}{*}{ M } & $\mathrm{T} 3774 \mathrm{~A}$ & $\mathrm{TGT} \rightarrow \mathrm{T} / \mathrm{AGT}$ & C171S or none \\
\hline & T9373C & $\mathrm{ATT} \rightarrow \mathrm{ATT} / \mathrm{C}$ & None \\
\hline & A11515T & $\mathrm{ACA} \rightarrow \mathrm{ACA} / \mathrm{T}$ & None \\
\hline \multirow[t]{3}{*}{$\mathrm{L}$} & T12106A & ATT $\rightarrow$ ATA & None \\
\hline & $\mathrm{C} 12111 \mathrm{~A} / \mathrm{C}$ & $\mathrm{TCT} \rightarrow \mathrm{TA} / \mathrm{CT}$ & S1225Y or none \\
\hline & A12977G/A & $\mathrm{ATT} \rightarrow \mathrm{G} / \mathrm{ATT}$ & I1514V or none \\
\hline
\end{tabular}


acid changes in the $\mathrm{L}$ protein. $\mathrm{P}$ and $\mathrm{L}$ proteins play a critical role in the replication of the virus. The RNA dependent RNA polymerase (RdRp) of paramyxoviruses, which contains a minimum of a homotetramer of $\mathrm{P}$ and a single $\mathrm{L}$ protein, transcibes the genome into 5 ' capped and 3 ' polyadenylated viral mRNAs. It is also involved in the synthesis of the exact complementary copy of the genome (antigenome), as well as the genome. Therefore, the amino acid variations in $\mathrm{P}$ and L proteins may modulate the enzymatic activity of the polymerase complex, although, this suggestion needs to be examined experimentally. Further studies based on reverse genetics are required to investigate the relationship between these diversities and the molecular mechanism of attenuation and/or virulence. In spite of the fact that genetic heterogeneity in other mumps vaccine strains has also been observed (Boriskin et al., 1992; Amexis et al., 2002; Sauder et al., 2006; Kosutic-Gulija et al., 2008; Tillieux et al., 2009), it might be necessary to prepare a cloned attenuated vaccine RS-12 virus as a genetically homogenous seed.

There is currently limited data available on sequencing of the full-length genomes of attenuated $\mathrm{MuV}$ vaccine strains. Although it was recently indicated that N/M proteins are involved in viral pathogenicity/attenuation of $\mathrm{MuV}$ (Sauder et al., 2011), these patterns have not been observed in all strains (Lemon et al., 2007; Malik et al., 2009; Liang et al., 2010; Xu et al., 2012). As a result, no unique differentiation marker has been found between parental wild and attenuated passages of different vaccine strains. The presented results indicate that the regulation of P-L polymerase complex activities (transcription/replication) and/or matrix protein, and/or accessory $\mathrm{V} / \mathrm{I}$ proteins activities may play a role in the diminution of pathogenicity of the vaccine strain RS-12.

Acknowledgements. The authors thank Dr. Zohreh-Azita Sadigh, Razi Institute, for constructive comments on preparing the manuscript. This work was supported by the grant No. 2-18-18-91119 from the Iran Agricultural Research, Education and Extension Organization (AREEO).

\section{References}

Alirezaie B, Aghaiypour K, Shafyi A (2008): Genetic characterization of RS-12 (S-12), an Iranian isolate of mumps virus, by sequence analysis and comparative genomics of $\mathrm{F}, \mathrm{SH}$, and HN genes. J. Med. Virol. 80, 702-710. http://dx.doi. org/10.1002/jmv.21087

Amexis G, Rubin S, Chizhikov V, Pelloquin F, Carbone K, Chumakov K (2002): Sequence diversity of Jeryl Lynn strain of mumps virus: quantitative mutant analysis for vaccine quality control. Virology 300, 171-179. http://dx.doi. org/10.1006/viro.2002.1499

Betáková T, Svetlíková D, Gocník M (2013): Overview of measles and mumps vaccine: origin, present, and future of vac- cine production. Acta Virol. 57, 91-96. http://dx.doi. org/10.4149/av $2013 \quad 0291$

Boriskin YS, Yamada A, Kaptsova TI, Skvortsova OI, Sinitsyna OA, Takeuchi K, Tanabayashi K, Sugiura A (1992): Genetic evidence for variant selection in the course of dilute passaging of mumps vaccine virus. Res. Virol. 143, 279-283. http://dx.doi.org/10.1016/S0923-2516(06)80116-0

Elliott GD, Yeo RP, Afzal MA, Simpson EJ, Curran JA, Rima BK (1990): Strain-variable editing during transcription of the $\mathrm{P}$ gene of mumps virus may lead to the generation of non-structural proteins NS1 (V) and NS2. J. Gen. Virol.71, 1555-1560. http://dx.doi.org/10.1099/00221317-71-7-1555

Esna-ashari F, Mirchamsy H, Shafyi A, Shams shahrabadi M, Sabiry GM, Sassani A, Hossein Zade T (2002): Humoral immune response to mumps (RS-12 strain) vaccine of children 1-7 years old. Arch. Razi Ins. 54, 77-84.

Feiterna-Sperling C, Brönnimann R, Tischer A, Stettler P, Durrer P, Gaedicke G (2005): Open randomized trial comparing the immunogenicity and safety of a new measles-mumpsrubella vaccine and a licensed vaccine in 12 - to 24-monthold children. Pediatr. Infect. Dis. J. 24, 1083-1088. http:// dx.doi.org/10.1097/01.inf.0000183746.92218.f9

Kosutic-Gulija T, Forcic D, Šantak M, Ramljak A, MateljakLukacevic S, Mazuran R (2008): Genetic heterogeneity of L-Zagreb mumps virus vaccine strain. Virol. J. 5, 1-8. http://dx.doi.org/10.1186/1743-422X-5-79

Lemon K, Rima BK, McQuaid S, Allen IV, Duprex WP (2007): The $\mathrm{F}$ gene of rodent brain-adapted mumps virus is a major determinant of neurovirulence. J. Virol. 81, 8293-8302. http://dx.doi.org/10.1128/JVI.00266-07

Liang Y, Ma S, Liu L, Zhao H, Wang L, Jiang L, Xie Z, Dong C, Li Q (2010): Identification and development of a promising novel mumps vaccine candidate strain. Microbes. Infect. 12, 1178-1187. http://dx.doi.org/10.1016/j. $\underline{\text { micinf.2010.08.004 }}$

Malik TH, Wolbert C, Nerret L, Sauder C, Rubin S (2009): Single amino acid changes in the mumps virus haemagglutininneuraminidase and polymerase proteins are associated with neuroattenuation. J. Gen. Virol. 90, 1741-1747. http://dx.doi.org/10.1099/vir.0.009449-0

McPherson MJ, Møller SG (2006): PCR. Taylor \& Francis Group, New York, pp. 23-62.

Sassani A, Mirchamsy H, Shafyi A, Ahourai P, Razavi J, Gholami R, Mohammadi A, Ezzi A, Rahmani M, Fateh G, Paravandi T (1991): Development of a new live attenuated mumps virus vaccine in human diploid cells. Biologicals 19, 203211. http://dx.doi.org/10.1016/1045-1056(91)90036-J

Sauder CJ, Vandenburgh KM, Iskow RC, Malik T, Carbone KM, Rubin SA (2006): Changes in mumps virus neurovirulence phenotype associated with quasispecies heterogeneity. Virology 350, 48-57. http://dx.doi.org/10.1016/j. virol.2006.01.035

Sauder CJ, Zhang CX, Ngo L, Werner K, Lemon K, Duprex WP, Malik T, Carbone K, Rubin SA (2011): Gene-specific contributions to mumps virus neurovirulence and neuroattenuation. J. Virol. 85, 7059-7069. http://dx.doi. org/10.1128/JVI.00245-11 
Shahkarami MK, Azad TM, Aghaiypour K, Shafyi A, Taqavian M, Mohammadi A (2012): Establishment of a standard seed lot system of an Iranian Mumps virus strain; RS-12, for mass production of mumps and MMR vaccines. Iran. Red Crescent Med. J. 14, 508-514.

Steffen C, Ankenbauer W, Bauer-Hofmann R, Bye S, Eisel D, Frey B, Keesey J, Rosenstraus M, Schäferkordt S, SchlichtHJ (1999): Roche Molecular Biochemicals: PCR Applications Manual. Auflage, Roche Diagnostics GmbH, Mannheim, pp. 9-50.
Tillieux SL, Halsey WS, Sathe GM, Vassilev V (2009): Comparative analysis of the complete nucleotide sequences of measles, mumps, and rubella strain genomes contained in Priorix-Tetra and ProQuad live attenuated combined vaccines. Vaccine 27, 2265-2273. http://dx.doi. org/10.1016/j.vaccine.2009.01.112

Xu P, Luthra P, Li Z, Fuentes S, D'Andrea JA, Wu J, Rubin S, Rota PA, He B (2012): The V protein of mumps virus plays a critical role in pathogenesis. J. Virol. 86, 1768-1776. http://dx.doi.org/10.1128/JVI.06019-11 